\title{
Editorial
}

\section{Circular Inference in Dementia Diagnostics}

\author{
Poul F. Høilund-Carlsen ${ }^{\mathrm{a}, \mathrm{b}, *}$, Jorge R. Barrio ${ }^{\mathrm{c}}$, Albert Gjedde ${ }^{\mathrm{a}, \mathrm{b}, \mathrm{d}}$, Thomas J. Werner ${ }^{\mathrm{e}}$ \\ and Abass Alavi ${ }^{\mathrm{e}}$ \\ ${ }^{a}$ Department of Nuclear Medicine, Odense University Hospital, Odense, Denmark \\ ${ }^{\mathrm{b}}$ Department of Clinical Research, University of Southern Denmark, Odense, Denmark \\ ${ }^{\mathrm{c}}$ Department of Molecular and Medical Pharmacology, David Geffen UCLA School of Medicine, \\ Los Angeles, CA, USA \\ ${ }^{\mathrm{d}}$ Department of Neuroscience and Pharmacology, University of Copenhagen, Copenhagen, Denmark \\ ${ }^{\mathrm{e}}$ Department of Radiology, Hospital of the University of Pennsylvania, Philadelphia, PA, USA
}

Accepted 31 January 2018

\begin{abstract}
Referring to recent international articles stating that amyloid imaging or detection has a high additive value in making a diagnosis of Alzheimer's disease (AD) when previous investigations are inconclusive, the authors of this editorial argue that this statement is based on circular reasoning and, hence, misleading. Since autopsy findings and other potential indicators fit poorly with amyloid PET, they conclude that this examination has no role in the diagnosis of AD.
\end{abstract}

Keywords: Alzheimer's disease, amyloid PET, circular inference, dementia

Circular inferences are conclusions based on assumptions that follow, rather than precede, the conclusions. It is not a new phenomenon in neuroscience [1-3]. A recent example is a report in the European Journal of Nuclear Medicine and Molecular Imaging (EJNMMI), authored by Brendel and co-workers [4]. The report immediately was cited by Health Imaging under the headline "Amyloid PET shows good additive value when standard PET isn't conclusive on dementia" [5]. This statement is misleading and dangerous because its circular message may help cement the claim that amyloid- $\beta(\mathrm{A} \beta)$ deposition determined by PET is beneficial to the management of patients with Alzheimer's disease (AD), and as such, superior to FDG deposition alone, as detected by PET. The EJNMMI article reports on $\left[{ }^{18} \mathrm{~F}\right]$ florbetaben $(\mathrm{FBB})$ PET in 107 patients with suspected dementia that remained unclarified after FDG-PET. It states that in

\footnotetext{
*Correspondence to: Poul F. Høilund-Carlsen, MD, DMSc, Prof (Hon), Professor of Clinical Physiology, Department of Nuclear Medicine, Odense University Hospital, 5000 Odense C, Denmark. Tel.: +45 25215445; E-mail: pfhc@rsyd.dk.
}

$83 \%$ of formerly unclear cases, a "final diagnosis was reached through FBB-PET, and the most likely prior diagnosis was changed in $28 \%$ of cases" [4].

The article [4] initially offers a reminder that appropriate use of amyloid imaging applies to patient groups with 1) early onset of progressive dementia; 2) atypical or mixed presentation of $\mathrm{AD}$; and 3) persistent or progressive unexplained mild cognitive impairment (MCI), according to the joint recommendations by the Society of Nuclear Medicine and Molecular Imaging and the Alzheimer's Association in the USA. In this way, the authors imply that the presented results meet these requirements, although they do not. Group \#1 was not a subject for the Brendel et al. article, and no study to date has been able to demonstrate that $A \beta$ PET can distinguish between early and late onset AD. In groups \#2 and \#3, the article states that FBB imaging has additive value, which unfortunately was not demonstrated, as this requires a study design with an infallible reference that answers with certainty whether or not AD was present. Had such a method existed, the current study would have 
no justification, but to reason inversely, that in the absence of a gold standard, the current study and its results are justified, is equally incorrect.

In brief, the article argues as follows: Amyloid plaques are a hallmark of $\mathrm{AD}$ and amyloid PET tracers like FBB are sensitive to the presence of brain amyloid pathology in vivo as confirmed by autopsy studies; therefore, FBB-PET can verify the presence or absence of AD by demonstrating amyloid deposits. Thus, the patients with MCI in the Brendel et al. study [4] had initially their most likely diagnosis established according to ICD-10 and "common diagnostic criteria", after undergoing cognitive testing, MRI, CSF sampling, and FDG-PET examinations. Patient diagnoses were discussed by an interdisciplinary dementia board, which recommended an additional amyloid-PET for 107 selected cases with remaining "uncertainty in the final diagnosis."

Of these, 65 were visually classified as amyloidpositive and in 61 of these 65 patients (94\%), a positive amyloid finding led to the "final diagnosis" for which no independent definitive reference was offered. The board could decide that the addition of an amyloid scan accomplished a stratification of patients that was helpful in $94 \%$ of cases, when in actual fact no one could tell whether that was right. Thus, the circle was closed: Amyloid means AD, FBB traces amyloid, and therefore amyloid positive FBB-PET findings are consistent with a correct final diagnosis, except in the few cases that remained equivocal even after FBB imaging [4].

This logic is faulty on several grounds: 1) The criteria for neuropathological diagnosis of AD (National Institutes of Aging-Alzheimer's Association (NIAAA)) from the Consortium to Establish a Registry for Alzheimer's Disease (CERAD) has established an "ABC" score for AD entailing a complex regional localization of tau and $A \beta$ neuro-aggregates rather than the mere presence of amyloid burden [6, 7]. 2) For this reason alone, current $A \beta$ imaging technology is not suitable to establish the diagnosis of $\mathrm{AD}$. If the presence of amyloid neuropathology in postmortem amyloid pathology cannot provide diagnosis of $\mathrm{AD}$, how can 'amyloid imaging' be used to accurately diagnose AD? For this reason, the FDA approval of FFB PET has been limited to the detection of amyloid aggregates, on the assumption that this is accurate.

We hope that regulatory and reimbursement authorities are not seduced by this kind of logic, to the detriment of patients and health expenditures. The logic begs the question when the authors argue that "AD is present because what we see with amyloid imaging when adding this to other findings can only be described as AD". Without proof, they create the impression that they obtained a clinically significant result when the addition of a positive amyloid scan resulted in a board-determined AD diagnosis in 61/65 (93\%) of patients with an amyloid positive scan, whereas the addition of a negative amyloid scan could rule out AD only in 28/42 (67\%) of cases with a negative scan. At the same time, the most likely prior diagnosis was changed in 14/65 (22\%) of cases in the former group versus 16/42 (38\%) in the latter [4]. We argue that this reasoning has no clinical value.

In their Decision Memo for Beta Amyloid Positron Emission Tomography in Dementia and Neurodegenerative Disease of September 2013, the Centers for Medicare \& Medicaid Services (CMS) state that they will cover only one PET A $\beta$ scan per patient through coverage with evidence development (CED) in clinical studies that meet the criteria in each of two scenarios: “(1) to exclude Alzheimer's disease (AD) in narrowly defined and clinically difficult differential diagnoses, such as AD versus frontotemporal dementia (FTD); and (2) to enrich clinical trials seeking better treatments or prevention strategies for $\mathrm{AD}$, by allowing for selection of patients on the basis of biological as well as clinical and epidemiological factors." To get coverage, clinical studies "must be approved by CMS, involve subjects from appropriate populations, and be comparative and longitudinal" [8]. These conditions were not met by many published studies trying to demonstrate the efficacy of amyloid imaging in the clinical setting, nor by the current report of Brendel et al.

The reference given by Brendel et al. for autopsy confirmation was a phase III clinical study of 216 patients demonstrating correlations between regional FBB SUVs and consensus panel histopathology scores for amyloid plaques in the middle frontal gyrus, occipital, anterior, and posterior cingulate cortex/precuneus but not in the hippocampus/parahippocampal gyrus of 74 deceased subjects [9]. However, $\rho$-values for significant correlations ranged between 0.40 and 0.70 , indicating no relations tight enough to characterize the individual patient as seen also in Fig. 3 of their supplementary material [9]. The Brendel et al. report further states [4] that "importantly, the results of amyloid-PET imaging bring added value in clinical management of individual patients", even when it adds that: "advanced age hampers the value of amyloid-PET, as positivity is present in more than $40 \%$ of cognitively healthy 
subjects older than 90 years." The latter qualification is correct, but Brendel et al. did not take full account of the article they cited. It is a meta-analysis of 2,914 participants with normal cognition, 697 with subjective cognitive impairment (SCI), and 3,972 with MCI aged 18 to 100 years. It demonstrated an increase in prevalence of 'amyloid imaging' positivity from $10 \%$ at age 50 to $44 \%$ at age 90 among participants with normal cognition; from $12 \%$ to $43 \%$ among patients with SCI; and from $27 \%$ to $71 \%$ among patients with MCI [10]. Interestingly, a meta-analysis made by the same group of 1,359 participants with clinically diagnosed $\mathrm{AD}$ showed a decrease in 'amyloid imaging' positivity from age 50 to 90 years in APOE $\varepsilon 4$ noncarriers from $86 \%$ to $68 \%$ and to a lesser degree in APOE $\varepsilon 4$ carriers [11]. Combined, the reasonable conclusion of these studies is that with such major overlaps between groups, amyloid imaging cannot characterize the individual patient, nor correctly confirm or reject the presence of AD.

The previously described high degrees of amyloid presence in the frontal lobe and white matter further questions the sensitivity and specificity of amyloid imaging agents in detecting $\operatorname{AD}[12,13]$. Together with neuropathological criteria for the AD diagnosis $[6,7]$, and a decrease in amyloid deposits with age in demented patients [11], it is increasingly evident that amyloid-PET has no place as a diagnostic tool for $\mathrm{AD}$.

A core element in the foundation of $A \beta$ imaging is the "Amyloid Hypothesis", i.e., the claim that amyloid deposition disrupts communication among neurons and eventually leaves them without synapses, and the additional claim that FBB and similar PET tracers actually mark pathologically important species of amyloid and not other tissue targets. Against these claims speaks the fact that neuropathological determinations unquestionably show that $A \beta$ plaques may be present in the brain of some normal controls, but rarely in "widespread, dense AD-type neocortical lesions in cases lacking documented ante mortem cognitive decline' [14]. If so, why would approximately $30 \%$ of cognitively normal control subjects, based on amyloid PET, have been reported to have an $A \beta$ load comparable with that found in AD patients [15]? An additional element against the validity of the concept is the large number of failures that anti-amyloid therapies have suffered during the last decade, see for example reference [16], a fate that recently also befell the antibody treatment of tau deposits that emerged in recent years as an alternative cause of AD [17].
Instead, it previously was said that amyloid deposits would be like open airbags in car accidents, just by-products of neuronal degeneration and not the reverse, such that removal of amyloid plaques not necessarily would bring back neurons that already are highly dysfunctional or dead [18]. Rather than providing added value for the diagnosis of $\mathrm{AD}$, amyloid imaging brings further confusion and little expectation that it would be of value in monitoring effects of upcoming new AD medicines. The high sensitivity of PET and the possibility of quantifying disease extent and severity do not benefit amyloid scanning, as long as the correct association between amyloid deposits and $\mathrm{AD}$ is questionable. At this moment, there is little doubt that FDG-PET imaging in AD is the approach that corresponds best with meaningful functional brain activity in patients with suspected dementia [12, 13], and has significant value in its diagnosis, as recognized by CMS approval for reimbursement [19].

The German group, which Brendel et al. belong to, reported earlier this year in another study authored by Daerr et al. about the use of early-phase dynamic FBB uptake as a surrogate marker of cerebral flow [20] as this may be a better way to establish the diagnosis of $\mathrm{AD}$ or rather discriminate between various forms of dementia as has recently been shown with ${ }^{11} \mathrm{C}$-PIB [21]. However, this is an entirely different ball game more in keeping with FDG PET imaging than with late-phase FBB PET.

It is indeed thought-provoking that the reported presence of cerebral amyloid deposits 20-30 years before symptoms develop [10] was not translated into common use of amyloid imaging to detect very early AD. FBB has been reported to increase the confidence of diagnosticians [22], but this does not mean that FBB imaging serves to make a diagnosis of AD, as claimed in the report by Brendel et al. The question of whether A $\beta$-PET can discriminate early onset from late onset $\mathrm{AD}$ has been addressed several times and the short answer is that it cannot [23,24]. A recent study aimed to evaluate the cost-effectiveness of the use of $\left[{ }^{18} \mathrm{~F}\right]$ florbetapir (FBP) as an adjunct to standard diagnostic assessment for the diagnosis of $\mathrm{AD}$ in France and found that $\mathrm{A} \beta$-PET used as an adjunct to standard diagnostic assessment increased quality adjusted life years (QALYs) by 0.021 years and 10 year costs by $€ 470$ per patient [25]. The authors, several of whom are employed by the company that produces FBP, concluded that $A \beta$-PET is likely to affordably increase QALYs. From an independent standpoint, we would conclude the opposite, namely 
that the use of A $\beta$-PET with FBP is not worth the effort or the cost.

The many reports on $A \beta$ imaging live their own self-reinforcing life based on the pervasive assumption that presence or absence of amyloid is determinant in the management of AD. An example of this is a brand new letter in Nature about the detection of $\mathrm{A} \beta$ biomarkers in blood, using PIB-PET as an assertive reference, which is the focus of circular reasoning [26]. As evidence of this inference, the authors indicate that when there is 'diagnostic uncertainty about a clinical diagnosis of $\mathrm{AD}, \mathrm{A} \beta$-PET is considered to have a major clinical effect', and that 'the plasma biomarker could be helpful for the differential diagnosis of $\mathrm{AD}$ and aid in determining therapeutic strategies, by providing additional information on the brain $\mathrm{A} \beta$ deposition status of individuals' [26].

Common to the failure of these claims, including the current report in EJNMMI, is the state-of-the-art that no infallible reference renders the conclusions unequivocal. Therefore, we ask why there is still faith in amyloid-PET as a diagnostic tool. From scientific and health-economic points of view, the diagnostic use of $A \beta$-PET has no justification. The load of insufficient or contradictory information including suboptimal sensitivity and specificity, mismatches among the location of pronounced pathological changes and typical amyloid deposits, insufficient distinction between early and late onset $\mathrm{AD}$, decreasing prevalence of amyloid plaques with age in demented persons, and minimal or non-existent costeffectiveness, all make for the conclusion that $A \beta$ PET has no place in the routine work-up of suspected AD.

\section{DISCLOSURE STATEMENT}

Authors' disclosures available online (https:// www.j-alz.com/manuscript-disclosures/18-0050r1).

\section{REFERENCES}

[1] Kriegeskorte N, Simmons WK, Bellgowan PS, Baker CI (2009) Circular analysis in systems neuroscience: The dangers of double dipping. Nat Neurosci 12, 535-540.

[2] Hahn U (2011) The problem of circularity in evidence, argument, and explanation. Perspect Psychol Sci 6, 172-182.

[3] Jardri R, Duverne S, Litvinova AS, Denève S (2017) Experimental evidence for circular inference in schizophrenia. Nat Commun 8, 14218.

[4] Brendel M, Schnabel J, Schönecker S, Wagner L, Brendel E, Meyer-Wilmes J, Unterrainer M, Schildan A, Patt M, Prix C, Ackl N, Catak C, Pogarell O, Levin J, Danek A, Buerger K, Barbtenstein P, Barthel H, Sabri O, Rominger A
(2017) Additive value of amyloid-PET in routine cases of clinical dementia work-up after FDG-PET. Eur J Nucl Med Mol Imaging 44, 2239-2248.

[5] Pearson D (2017) Amyloid PET shows good additive value when standard PET isn't conclusive on dementia, Health Imaging. http://www.healthimaging.com/topics/molecularimaging/amyloid-pet-shows-good-additive-value-whenstandard-pet-isnt-conclusive-dementia. Posted 27 September 2017, Accessed 12 January 2018.

[6] Montine TJ, Phelps CH, Beach TG, Bigio EH, Cairns NJ, Dickson DW, Duyckaerts C, Frosch MP, Masliah E, Mirra SS, Nelson PT, Schneider JA, Thal DR, Trojanowski JQ, Vinters HV, Hyman BT (2012) National Institute on AgingAlzheimer's Association guidelines for the neuropathologic assessment of Alzheimer's disease: A practical approach. Acta Neuropathol 123, 1-11.

[7] Hyman BT, Phelps CH, Beach TG, Bigio EH, Cairns NJ, Carrillo MC, Dickson DW, Duyckaerts C, Frosch MP, Masliah E, Mirra SS, Nelson PT, Schneider JA, Thal DR, Thies B, Trojanowski JQ, Vinters HV, Montine TJ (2012) Institute on Aging-Alzheimer's Association guidelines for the neuropathologic assessment of Alzheimer's disease. Alzheimers Dement 8, 1-13.

[8] Jacques L, Jensen TS, Rollins J, Coachman BB, Caplan S, Hakim R, Roche J, Hutter J (2013) Decision memo for beta amyloid positron emission tomography in dementia and neurodegenerative disease (CAG-00431N). The Centers for Medicare \& Medicaid Services, https://www.cms.medi care-coverage-database/details/nca-decision-memo.aspx? NCAId=265. Posted 27 September 2013, Accessed 12 January 2018.

[9] Sabri O, Sabbagh MN, Seibyl J, Barthel H, Akatsu H, Ouchi Y, Senda K, Murayama S, Ishii K, Takao M, Beach TG, Rowe CC, Leverenz JB, Ghetti B, Ironside JW, Catafau AM, Stephens AW, Mueller A, Koglin N, Hoffmann A, Roth K, Reininger C, Schulz-Schaeffer WJ; Florbetaben Phase 3 Study Group (2015) Florbetaben PET imaging to detect amyloid beta plaques in Alzheimer's disease: Phase 3 study. Alzheimers Dement 11, 964-974.

[10] Jansen WJ, Ossenkoppele R, Knol DL, Tijms BM, Scheltens P, Verhey FR, Visser PJ; Amyloid Biomarker Study Group, Aalten P, Aarsland D, Alcolea D, Alexander M, Almdahl IS, Arnold SE, Baldeiras I, Barthel H, van Berckel BN, Bibeau K, Blennow K, Brooks DJ, van Buchem MA, Camus V, Cavedo E, Chen K, Chetelat G, Cohen AD, Drzezga A, Engelborghs S, Fagan AM, Fladby T, Fleisher AS, van der Flier WM, Ford L, Förster S, Fortea J, Foskett N, Frederiksen KS, Freund-Levi Y, Frisoni GB, Froelich L, Gabryelewicz T, Gill KD, Gkatzima O, Gómez-Tortosa E, Gordon MF, Grimmer T, Hampel H, Hausner L, Hellwig S, Herukka SK, Hildebrandt H, Ishihara L, Ivanoiu A, Jagust WJ, Johannsen P, Kandimalla R, Kapaki E, KlimkowiczMrowiec A, Klunk WE, Köhler S, Koglin N, Kornhuber J, Kramberger MG, Van Laere K, Landau SM, Lee DY, de Leon M, Lisetti V, Lleó A, Madsen K, Maier W, Marcusson J, Mattsson N, de Mendonça A, Meulenbroek O, Meyer PT, Mintun MA, Mok V, Molinuevo JL, Møllergård HM, Morris JC, Mroczko B, Van der Mussele S, Na DL, Newberg A, Nordberg A, Nordlund A, Novak GP, Paraskevas GP, Parnetti L, Perera G, Peters O, Popp J, Prabhakar S, Rabinovici GD, Ramakers IH, Rami L, Resende de Oliveira C, Rinne JO, Rodrigue KM, Rodríguez-Rodríguez E, Roe CM, Rot U, Rowe CC, Rüther E, Sabri O, Sanchez-Juan P, Santana I, Sarazin M, Schröder J, Schütte C, Seo SW, Soetewey F, Soininen H, Spiru L, Struyfs H, Teunissen CE, Tsolaki 
M, Vandenberghe R, Verbeek MM, Villemagne VL, Vos SJ, van Waalwijk van Doorn LJ, Waldemar G, Wallin A, Wallin ÅK, Wiltfang J, Wolk DA, Zboch M, Zetterberg H (2015) Prevalence of cerebral amyloid pathology in persons without dementia: A meta-analysis. JAMA 313, 1924-1938.

[11] Ossenkoppele R, Jansen WJ, Rabinovici GD, Knol DL, van der Flier WM, van Berckel BN, Scheltens P, Visser PJ; Amyloid PET Study Group, Verfaillie SC, Zwan MD, Adriaanse SM, Lammertsma AA, Barkhof F, Jagust WJ, Miller BL, Rosen HJ, Landau SM, Villemagne VL, Rowe CC, Lee DY, Na DL, Seo SW, Sarazin M, Roe CM, Sabri O, Barthel H, Koglin N, Hodges J, Leyton CE, Vandenberghe R, van Laere K, Drzezga A, Forster S, Grimmer T, Sánchez-Juan P, Carril JM, Mok V, Camus V, Klunk WE, Cohen AD, Meyer PT, Hellwig S, Newberg A, Frederiksen KS, Fleisher AS, Mintun MA, Wolk DA, Nordberg A, Rinne JO, Chételat G, Lleo A, Blesa R, Fortea J, Madsen K, Rodrigue KM, Brooks DJ (2015) Prevalence of amyloid PET positivity in dementia syndromes: A meta-analysis. JAMA 313, 1939-1349.

[12] Moghbel MC, Saboury B, Basu S, Metzler SD, Torigian DA, Langstrom B, Alavi A (2012) Amyloid- $\beta$ imaging with PET in Alzheimer's disease: Is it feasible with current radiotracers and technologies? Eur J Nucl Med Mol Imaging 39, 202-208.

[13] Kepe V, Moghbel MC, Långström B, Zaidi H, Vinters HV, Huang SC, Satyamurthy N, Doudet D, Mishani E, Cohen RM, Høilund-Carlsen PF, Alavi A, Barrio JR (2013) Amyloid- $\beta$ positron emission tomography imaging probes: A critical review. J Alzheimers Dis 36, 613-631.

[14] Nelson PT, Alafuzoff I, Bigio EH, Bouras C, Braak H, Cairns NJ, Castellani RJ, Crain BJ, Davies P, Del Tredici K, Duyckaerts C, Frosch MP, Haroutunian V, Hof PR, Hulette CM, Hyman BT, Iwatsubo T, Jellinger KA, Jicha GA, Kövari E, Kukull WA, Leverenz JB, Love S, Mackenzie IR, Mann DM, Masliah E, McKee AC, Montine TJ, Morris JC, Schneider JA, Sonnen JA, Thal DR, Trojanowski JQ, Troncoso JC, Wisniewski T, Woltjer RL, Beach TG (2012) Correlation of Alzheimer disease neuropathologic changes with cognitive status: A review of the literature. J Neuropathol Exp Neurol 71, 362-381.

[15] Jack C, Barrio JR, Kepe V (2013) Cerebral amyloid PET imaging in Alzheimer's disease. Acta Neuropathol 126, 643-657.

[16] Belluck P (2016) Eli lilly's experimental Alzheimer's drug fails in large trial. New York Times. https://www.nytimes. com/2016/11/23/health/eli-lillys-experimental-alzheimersdrug-failed-in-large-trial.html\#story-continues-1. Posted 23 November 2016, Accessed 12 January 2018.

[17] Pollack A (2016) Alzheimer's drug LMTX falters in final stage of trials. New York Times. https://www.nytimes.com/ 2016/07/28/business/alzheimers-drug-lmtx-trial.html?action $=$ click \& contentCollection $=$ Health $\&$ module $=$ RelatedCover age \&region $=$ Marginalia\&pgtype $=$ article. Posted 27 July 2016. Accessed 12 January 2018.
[18] Krstic D, Knuesel I (2013) The airbag problem-a potential culprit for bench-to-bedside translational efforts: Relevance for Alzheimer's disease. Acta Neuropathol Commun 1, 62.

[19] Phurrough S, Salive M, Richardson S, Cano C (2004) Decision Memorandum for FDG-PET for diagnosis of early dementia in elderly patients for whom the differential diagnosis includes neurodegenerative diseases. The Centers for Medicare and Medicaid Services. https://www.cms.gov/ medicare-coverage-database/details/nca-decision-memo. aspx ?NCAId=104. Posted 15 September 2004, Accessed 12 January 2018.

[20] Daerr S, Brendel M, Zach C, Mille E, Schilling D, Zacherl MJ, Bürger K, Danek A, Pogarell O, Schildan A, Patt M, Barthel H, Sabri O, Bartenstein P, Rominger A (2016) Evaluation of early-phase [18F]-florbetaben PET acquisition in clinical routine cases. Neuroimage Clin 14, 77-86.

[21] Rodell AB, O'Keefe G, Rowe CC, Villemagne VL, Gjedde A (2017) Cerebral blood flow and $A \beta$-amyloid estimates by WARM analysis of [11C]PiB uptake distinguish among and between neurodegenerative disorders and aging. Front Aging Neurosci 8, 321.

[22] Schipke CG, Peters O, Heuser I, Grimmer T, Sabbagh MN, Sabri O, Hock C, Kunz M, Kuhlmann J, Reininger C, Blankenburg M (2012) Impact of beta-amyloid-specific florbetaben PET imaging on confidence in early diagnosis of Alzheimer's disease. Dement Geriatr Cogn Disord 33, 416-422.

[23] Cho H, Seo SW, Kim JH, Suh MK, Lee JH, Choe YS, Lee KH, Kim JS, Kim GH, Noh Y, Ye BS, Kim HJ, Yoon CW, Chin J, Na DL (2013) Amyloid deposition in early onset versus late onset Alzheimer's disease. J Alzheimers Dis 35, 813-821.

[24] Youn YC, Jang JW, Han SH, Kim H, Seok JW, Byun JS, Park KY, An SSA, Chun IK, Kim S (2017) 11C-PIB PET imaging reveals that amyloid deposition in cases with early-onset Alzheimer's disease in the absence of known mutations retains higher levels of PIB in the basal ganglia. Clin Interv Aging 12, 1041-1048.

[25] Hornberger J, Bae J, Watson I, Johnston J, Happich M (2017) Clinical and cost implications of amyloid beta detection with amyloid beta positron emission tomography imaging in early Alzheimer's disease - the case of florbetapir. Curr Med Res Opin 33, 675-685.

[26] Nakamura A, Kaneko N, Villemagne VL, Kato T, Doecke J, Doré V, Fowler C, Li Q-X, Martins R, Rowe C, Tomita T, Matsuzaki K, Ishii K, Ishii K, Arahata Y, Iwamoto S, Ito k, Tanaka K, Colin L. Masters CL, Yanagisawa K (2018) High performance plasma amyloid- $\beta$ biomarkers for Alzheimer's disease. Nature 554, 249-254. 